\title{
PELAKSANAAN PENDIDIKAN AGAMA ISLAM DI SMPLB NEGERI BALIKPAPAN
}

\author{
Islamic Religion Education in SMPLB Negeri Balikpapan
}

\author{
Rosdiana \\ Balai Penelitian dan Pengembangan Agama Makassar \\ Jl. AP. Pettarani No. 72 Makassar 90222 \\ Email: rosdianalitbang03@gmail.com
}

Naskah diterima tanggal 17 April 2013. Naskah direvisi tanggal 30 April 2013. Naskah disetujui tanggal 29 Mei 2013

\begin{abstract}
Abstrak
Penelitian pada siswa berkebutuhan khusus ini bertujuan untuk mengetahui pelaksanaan pembelajaran PAI dan faktor pendukung dan penghambat pelaksanaan pembelajaran tersebut. Studi ini dilakukan di Sekolah Luar Biasa Negeri Balikpapan dengan menggunakan pendekatan kualitatif. Hasil penelitian ini menyimpulkan bahwa pelaksanaan pembelajaran PAI pada siswa berkebutuhan khusus disesuaikan dengan kemampuan siswa namun tetap berdasar pada standar nasional, kekhususan disabilitas siswa peserta didik perlu diperhatikan untuk mengefektifkan proses pembelajaran PAI, perencanaan pembelajaran, model pembelajaran, metode pembelajaran serta media pembelajaran memperlihatkan implementasi pada pelaksanaan pembelajaran. Perbedaan ditunjukkan pada aspek evaluasi yang tidak di sarankan bagi semua siswa kecuali bagi siswa yang mampu mengikuti evaluasi. Salah satu faktor penghambat adalah kompetensi guru PAI dalam aktivitas pembelajaran dan ketersediaannya sangat dibutuhkan, menjadi sebuah dilema bagi siswa berkebutuhan khusus dalam memperoleh pendidikan agama secara maksimal.
\end{abstract}

Kata kunci: pelaksanaan, pendidikan agama, anak berkebutuhan khusus

\begin{abstract}
Raden Ja'far Shodiq, Sunan Kudus to attempt islamic doctines at Kudus Regency, not centralized missionary endeavor in Kauman the place of Al-Aqsha Mosque building. The other place he builds outside of Al-Aqsha Mosque territory is Wali Mosque at Jepang Village Sub-district of Mejobo Kudus Regency. This research classified as social historical study by qualitative types. To collects data by, heuristic, interpretation, source criticism, and historiography. Furthermore, the sources of data are written, material, and oral resources. This research be implemented begin at February 2012 until July 2012. This research discovers Wali Mosque has really historical correlations with Menara Mosque, as dated $956 \mathrm{H}(1549 \mathrm{BC})$. The realities are visibling by the same space arrangements as encircle Wali Mosque. Padureksa Gate located ahead of mosque and the assignment of graves of figures lying down behind the mosque as like the lying down of Sunan Kudus grave locating in the wake of Menara Kudus Mosque.
\end{abstract}

\section{PENDAHULUAN}

$\mathrm{P}$ endidikan agama dalam sistem pendidikan nasional merupakan salah satu jenis pendidikan yang didesain dan diberikan kepada peserta didik untuk mengembangkan keberagamaan mereka (Thoha, 1994: 4). Hal ini mengisyaratkan bahwa dalam sistem pendidikan ada keseimbangan antara pengembangan potensi fisik dan mental, potensi intelektual dan spiritual, sebagai hal esensial dalam pembangunan manusia Indonesia seutuhnya.

Pendidikan bagi anak berkebutuhan khusus bertujuan untuk membentuk siswa mampu berprestasi dalam kelompoknya, baik secara sosial maupun emosional sebatas kemampuannya (Nuraeni, 1997: 104-105). Sekolah Luar Biasa (SLB) mengalami pertumbuhan yang pesat, terdapat di setiap provinsi bahkan kabupaten/kota dengan jenis, jumlah, dan jenjang yang bervariasi, mulai 
dari TK, SD, SMP, sampai SMA. Berdasarkan data pada Direktorat Pendidikan Khusus dan layanan khusus Dirjen Diknas Kemendikbud tahun 2013, terhadap 11 Provinsi di KTI yang menjadi wilayah kerja Balai Litbang Agama Makassar, tercatat 187 SLB dengan jumlah siswa 7.617 orang.

Penelitian tentang SLB baik secara umum maupun terkait pendidikan, beberapa kajian penelitian yang telah dilakukan, diantaranya: penelitian yang dilakukan oleh peneliti Balai Litbang Agama Semarang tentang pelaksanaan pendidikan agama pada Sekolah Luar Biasa yang dilakukan di tiga provinsi dalam wilayah kerja Balai Litbang Agama Semarang tahun 2009. Fokus penelitian adalah tentang pembelajaran Pendidikan Agama Islam pada SDLB, yang meliputi bagaimana guru menyusun kurikulum, menyusun silabus, menyusun rencana pelaksanaan pembelajaran hingga kegiatan pembelajaran. Aspek kurikulum pendidikan agama dengan perangkatnya, nampaknya belum memiliki dokumen yang memadai. Walaupun dipahami bahwa kurikulum dan penghayatannya adalah salah satu aspek penting dalam pembelajaran.

Penelitian tersebut $\mathrm{di}$ atas memiliki keterkaitan dan perbedaan dengan penelitian tentang pendidikan agama pada SLB di Kawasan Timur Indonesia, yang dilakukan oleh Balai Litbang Agama Makassar. Diantara perbedaan itu adalah penelitian di lakukan di wilayah kerja yang berbeda.Sasaran dan fokus penelitian dilakukan secara variatif mencakup berbagai jenjang, jenis, dan kualifikasi serta latar belakang pembelajaran pendidikan agama yang dilakukan di SLB. Penelitian ini mempelajari keterlaksanaan pembelajaan pendidikan agama yang dilakukan di Sekolah Menengah Pertama Luar Biasa (SMPLB)Negeri di Propinsi Kalimantan Timur, adapun pertanyaan dalam penelitian ini adalah bagaimana pelaksanaan pembelajaran pendidikan agama pada Sekolah Menengah Pertama Negeri Balikpapan Provinsi kKalimantan Timur? dan apa faktor pendukung dan penghambat dalam pelaksanaan pembelajaran pendidikan agama di SMPLB Negeri Balikpapan?

Ruang lingkup penelitian ini meliputi tentang keterlaksanaan pembelajaran pendidikan agama di SMPLB Negeri Balikpapan, serta faktor-faktor yang mempengaruhi keterlaksanaan pendidikan agama di SMPLB Negeri Balikpapan. Dari kedua lingkup penelitian tersebut dijabarkan dalampendidikan agama yang diajarkan di Sekolah Menengah Pertama Luar Biasa (SMPLB) Negeri Balikpapan, yakni Pendidikan Agama Islam. Keterlaksanaan pembelajaran pendidikan agama meliputi: peserta didik, karakteristik pendidikan, kurikulum, guru, sarana dan prasarana (Sarpras), media, metode, sumber belajar, serta evaluasi pembelajaran. Faktor-faktor pendukung dan penghambat yang mempengaruhi keterlaksanaan pembelajaran pendidikan agama di SMPLB Negeri Balikpapan.

\section{Tinjauan Pustaka}

pendidikan agama adalah bahagian dari sistem pendidikan nasional. Pada peraturan Menteri Agama RI Nomor 16 Tahun 2010 tentang pengelolaan pendidikan agama pada sekolah, pada Bab I pasal 1 ayat 1 disebutkan pendidikan adalah pendidikan yang memberikan, pengetahuan dan membentuk sikap, kepribadian dan keterampilan peserta didik dalam mengamalkan ajaran agamanya, yang dilaksanakan sekurang-kurangnya melalui mata pelajaran pada semua jalur, jenjang dan jenis pendidikan. Sekolah Luar Biasa adalah sekolah yang menyelenggarakan pembelajaran terhadap anak-anak berkebutuhan khusus, disebabkan olah kekurangan kesempurnaan keadaan fisik maupun mental mereka, sehingga mereka menyandang ketunaan.

Anak penyandang ketunaan dapat diartikan sebagai anak cacat, anak luar biasa, anak berkelainan atau anak berkebutuhan khusus. Dalam bahasa Inggris anak penyandang ketunaan disebut sebagai handicapped children atau exceptional children (Abdurrahman, 2004: 7).Menurut World Health Organization (WHO) handicap adalah sebuah keadaan merugikan yang dialami oleh individu sehingga mengakibatkan kelemahan atau ketidakmampuan serta membatasi peran individu (Abdurrahman, 2004: 7-8) yang termasuk kedalam golongan handicapped children diantaranya adalah buta, tuli, bentuk badan tidak normal, dan anakanak yang mempunyai sifat-sifat jasmani yang tidak normal. Anak-anak penderita cacat jasmani secara psikis mengalami beberapa masalah yaitu biasanya mereka mengalami kelainan atau perubahan pada energi syarafnya.

Landasan hukum yang melatarbelakangi penelitian ini adalah Peraturan Menteri Agama RI No. 16 Tahun 2010 pada Bab I pasal 1 ayat 1 dan 2 yang mengharuskan pendidikan agama melalui mata pelajaran di sekolah, termasuk pada SLB. Pasal 37 ayat (1) menegaskan bahwa isi kurikulum pendidikan dasar dan menengah wajib memuat, antara lain pendidikan agama. Dalam 
pasal 30 ayat 2 menjelaskan bahwa pendidikan keagamaan berfungsi menyiapkan peserta didik menjadi anggota masyarakat yang memahami dan mengamalkan nilai-nilai ajaran agamanya dan menjadi ahli ilmu agama.

Anak-anak yang mengalami cacat fisik, mental, dan mengalami masalah-masalah emosional, memerlukan pelayanan pendidikan, sosial, psikologi dan medis secara lebih. Mereka juga berharap memperoleh kesempatan untuk mendapat pengakuan dari masyarakat sekitarnya. Sifat-sifat pribadi yang menonjol yang dapat dilihat dari anak penyandang ketunaan ini adalah biasanya mereka memiliki perasaan yang halus, penakut dan pemalu, dan merasa inferior (minder). Sehingga tidaklah bijak jika kita sebagai manusia normal khususnya guru dan orang tua terlalu melindungi secara berlebihan terhadap mereka (Gate, 1950:721).

\section{Konsep Pembelajaran}

Pembelajaran dalam persekolahan, menurut Dimiyati dan Mudjiono (lihat Yusuf, 2005: 195) pembelajaran merupakan kegiatan guru secara terprogram dalam mendesain intruksional, untuk membuat siswa belajar aktif, yang menekankan pada sumber belajar. Bahkan dalam Undang-undang No. 20 Tahun 2003 tentang Sisdiknas menyatakan bahwa pembelajaran adalah proses interaksi peserta didik dengan pendidik dan sumber belajar pada suatu lingkungan belajar.

Sebagai sebuah proses interaksi, menurut Syaiful Sagala (2005: 63), melibatkan tiga komponen utama yaitu guru (pendidik), siswa (peserta didik) dan kurikulum, didukung oleh metode, media, dan sumber belajar yang digunakan. Sinkronisasi antar komponen itu diperlukan untuk mengembangkan kreatifitas dan kemampuan berfikir siswa, terutama dalam meningkatkan penguasaan yang baik terhadap mata pelajaran.

Menurut Sopandi (2008: 121-122) pembelajaran sebagai sistem, mencakup beberapa komponen, dintaranya: Siswa (peserta didik), sebagai input yang akan diproses menuju perkembangan dan perubahan yang diharapkan. Kurikulum, merupakan seperangkat program yang disusun untuk ditempuh siswa guna menyelesaikan pendidikannya. Guru (pendidik), individu yang melaksanakan pembelajaran, berperan sebagai fasilisator yang mampu merancang, melaksanakan, dan mengevaluasi pembelajaran yang dilakukannya. sarana dan prasarana, sebagai pendukung dalam proses pembelajaran sangat diperlukan terkait dengan keberadaan peserta didik untuk mempermudah pembelajaran di dalam dan di luar kelas. metode, merupakan bagian dari strategi guru dalam proses pembelajaranagar berjalan sesuai tujuan yang akan dicapai dan materi bahasan. Media, sebagai alat perantara antara guru dengan pesan materi yang akan disampaikan pada siswa penggunaannya sangat penting karena membantu siswa dalam mengikuti proses pembelajaran dan memahami materi pelajaran yang diberikan. Sumber belajar, merupakan pendukung yang penting dalam proses pembelajaran. Sumber belajar bukan hanya guru, namun dapat berupa pemberdayaan lingkungan sekolah, sehingga siswa dapat secara langsung mengalami proses peralihan pengetahuan secara kontruktifisme. Out put, hasil dari proses pembelajaran berkaitan dengan penguasaan siswa terhadap materi pembelajaran yang dapat dilihat saat ataupun setelah pembelajaran melalui evaluasi.

Menurut Carcy pembelajaran adalah suatu proses di mana lingkungan seseorang secara sengaja dikelola untuk memungkinkan ia turut serta dalam tingkah laku tertentu dalam kondisi-kondisi khusus atau menghasilkan respon terhadap situasi tertentu (Mulyono, 1994: 7).

Para ahli pendidikan, terutama yang konsen terhadap ilmu pembelajaran, mengembangkan berbagai model pembelajaran yang diaplikasikan dalam berbagai bidang pembelajaran. Salah satu di antaranya adalah pendekatan pembelajaran individu, di dalamnya dikembangkan model pembelajaran yang diasumsikan dapat diterapkan di SLB. Model-model pembelajaran tersebut sebagai berikut; model pembelajaran tidak langsung (non directive teaching), model pembelajaran pelatihan kesadaran (awareness training), dan model pembelajaran pertemuan kelas.

\section{METODE PENELITIAN}

Penelitian ini dilakukan di Kota Balikpapan Provinsi Kalimantan Timur. Dengan sasaran lokasi penelitian adalah SMPLB Negeri Kota Balikpapan. Penelitian ini merupakan penelitian kualitatif, peneliti menjadi bagian dari key instrument (Bogdan, 1982: 27). Peneliti ini mencoba memperoleh gambaran tentang keterlaksanaan pembelajaran pendidikan agama di SMPLB Negeri Balikpapan, kualifikasi dan kompetensi guru agama di SMPLB Negeri Balikpapan, selain itu, gambaran lain yang ingin diketahui adalah mengenai faktor pendukung 
dan penghambat dalam penerapan pendidikan pembelajaran Agama di SMPLB Negeri Balikpapan.

Sumber data dalam penelitian ini dibagi menjadi dua yaitu sumber primer dan sekunder. Sumber primer berhubungan langsung dengan objek penelitian yaitu pendidik (guru) mata pelajaran pendidikan agama SMPLB Negeri Balikpapan, Kepala SLB Negeri Balikpapan, orang tua siswa, pengawas dan komite SLB Negeri. Sedangkan sumber sekunder adalah dokumen-dokumen yang sifatnya sebagai pendukung, misalnya dokumen keadaan sekolah (fisik, ketenagaan, visi misi, ataupun profil SMPLB Negeri Balikpapan dokumen kurikulum dan muatan kurikulum, silabus dan rencana pelaksanaan pembelajaran, dan lain-lain, di internal SMPLB Negeri Balikpapan.

Instrumen yang digunakan untuk menggali data dalam penelitian ini dapat menggunakan beberapa teknik yaitu: observasi (pengamatan), wawancara, dan dokumentasi. Dalam penelitian ini analisis yang digunakan adalah model analisis data interaksi yang dilakukan oleh Anselm Strauss (2007: 100) yaitu menghubungkan antara kategori dengan sub kategori untuk kemudian dicari polapolanya. Adapun langkah-langkah yang digunakan dalam analisis ini adalah reduksi data, penyajian data dan verifikasi data (Sugiono, 2005:92).Kegiatan analisis dapat dilakukan sejak pengumpulan data di lapangan sampai penulisan laporan hasil penelitian.

\section{PEMBAHASAN \\ Profil SMPLB Negeri Balikpapan Identitas SMPLB Negeri Balikpapan}

SMPLB Negeri Balikpapan terletak di Jl. Syarifuddin Yoes (Perum Balikpapan Kota) Rt. 89 Kelurahan Gunung Bahagia Kecamatan Balikpapan Selatan, menempati area 2,1 hektar. SMPLB Negeri Balikpapan berada dalam satu atap yang dipimpin oleh satu kepala sekolah. Masing-masing tingkatan yang ada di Sekolah Luar Biasa (SLB) Negeri Balikpapan adalah TKLB, SDLB, SMPLB, dan SMALB. Sebelum menempati lokasi ini SLB Negeri Balikpapan pada awalnya berlokasi di Sepinggan samping bandara Internasional Sepinggan. Pasca kebakaran tahun 2004 lokasi SLB Negeri pindah lokasi yang ditempati sekarang ini sejak tahun 2006. Pada awalnya SLB Negeri Balikpapan merupakan SDLB yang didirikan pada tahun 1984. Peralihan status dari SDLB Negeri menjadi SLB Negeri berdasarkan SK kepala Dinas Pendidikan Provinsi Kalimantan Timur Nomor 90/K.827/IV/2006.
Tanggal 19 April 2006 di Samarinda. SLB Negeri Balikpapan memiliki nomor statistik sekolah 801.1661.01.001 dan nomor NPSN 30401525. Dalam perjalanannya keberadaan SLB Negeri Balikpapan dewasa ini telah memiliki jenjang Pendidikan TK, SD, SMP, dan SMA. Untuk tingkat pendidikan TKLB operasionalnya pada tahun 2005/2006, tingkat SDLB tahun operasionalnya adalah 1983/1984, tingkat SMPLB operasionalnya tahun 2005/2006, dan untuk tingkat SMALB tahun operasionalnya pada tahun 2008/2009. Status akreditasi yang dimiliki SLB Negeri Balikpapan adalah akreditasi A yang diperoleh pada tahun 2009.

Visi, misi, dan tujuan Sekolah Luar Biasa Negeri Balikpapan yakni: visi Sekolah Luar BIasa Negeri Balikpapan, adalah terwujudnya generasi berakhlak mulia, berbudi pekerti luhur, unggul dalam prestasi, dan mandiri. Misi sekolah, menanamkan, memberi tauladan yang benar dan baik di dalam kehidupan; mendorong untuk menjalankan ajaran agama sesuai yang dianut setiap anak didik; menanamkan pendidikan kewirausahaan dan kemandirian, dan; memberikan ilmu pengetahuan dan teknologi, program umum dan program khusus sesuai kemampuan anak didik. Tujuan sekolah, adalah: diharapkan anak didik tumbuh menjadi generasi yang dapat beribadah sesuai ajaran agama; dapat hidup di tengah masyarakat tanpa ada perbedaan; layak di masyarakat; anak didik mandiri dan bisa memenuhi kebutuhan hidupnya tanpa membebani orang lain, dan; memberi pandangan kepada orang tua masyarakat tentang kemampuan yang dimiliki.

\section{Keadaan Guru SMPLB Negeri Balikpapan}

Keadaan guru SLB Negeri Balikpapan untuk tahun ajaran 2012-2013 secara keseluruhan adalah 49 orang, terdiri guru PNS sebanyak 34 orang dan guru non PNS 15 orang, tenaga nonkependidikan sebanyak 4 orang. Keberadaan guru pendidikan agama di SLB Negeri Balikpapan secara keseluruhan sebanyak tiga orang. Guru agama Islam yang ada di SLB Negeri Balikpapan merupakan pengangkatan dari Diknas Pendidikan dan Departemen Agama dengan pengangkatan untuk jenjang SDLB dan belum ada pengangkatan guru PAI pada jenjang TKLB, SMPLB, dan SMALB. Di antaranya guru agama Islam dua orang dan guru agama Katolik (guru Kristen) satu orang. Pengajaran yang dilakukan oleh guru agama tersebut adalah mengajar pada semua jenjang pendidikan TK, SDLB, SMPLB, dan SMALB. Dengan keberadaan guru-guru agama dengan 
penempatan pada tingkat SDLB secara otomatis kelengkapan dan perangkat pembelajaran seperti RPP dilakukan oleh guru-guru agama tersebut hanya melengkapi perangkat pembelajaran PAI tingkat SDLB apalagi kelengkapan administrasi bagi guru PAI yang sudah tersertifikasi tingkat SDLB. Pada implementasi pembelajaran tingkat SMPLB yang dilakukan guru agama Islam tetap merujuk pada Kurikulum Tingkat Satuan Pendidikan (KTSP) tahun 2006.

Aspek kelengkapan perangkap pembelajaran guru juga menjadi aspek supervisi administrasi perencanaan pembelajaran yang dilakukan oleh kepala sekolah dan Pengawas PAI tingkat dasar seperti kelengkapan komponen administrasi pembelajaran, diantaranya: program tahunan, program semester, silabus, RPP, kalender pendidikan , jadwal tatap muka, agenda harian, daftar nilai, KKM, dan absensi siswa. Selain itu, aspek supervisi kegiatan pendidikan (sesuai dengan standar proses) yakni sub komponen dan butir komponen (tatap muka) juga menjadi penilaian bagi pengawas seperti kegiatan pendahuluan, kegiatan inti pembelajaran (elaborasi, eksplorasi dan konfirmasi), dan kegiatan penutup (wawancara Djaswadi, 18/4/ 2013).

Keberadaan guru Sekolah Luar Biasa terwadahkan lewat organisasi IGPLB (Ikatan Guru Pendidikan Luar Biasa). Dalam wadah ini beranggotakan seluruh guru SLB Se KAlimantan Timur yang di ketua oleh Agus Prasetya, M.Pd. Wadah ini dalam kegiatannya selama ini dilakukan pertemuan satu tahun sekali, biasanya dirangkaikan dengan halal bi halal setelah lebaran di bulan Syawal. Selain kegiatan pertemuan seperti ini biasanya juga dilakukan ceramah agama, seminar atau workshop. Kegiatan ini dilakukan bergilir pada masing-masing sekolah (wawancara Agus Prasetya, 08/03/2013). SLB Negeri Balikpapan menjadi pelaksanan sekaligus tuan rumah pada kegiatan ini pada tahun 2011. Selain itu, untuk kelompok kerja guru PAI SDLB Negeri Balikpapan terdapat KKG (Kelompok Kerja Guru) untuk wilayah Balikpapan Selatan. Dan untuk MGMP PAI Kota Balikpapan belum diikuti oleh guru PAI SMPLB Negeri Balikpapan.

Sementara guru agama Islam (Suyitno, S.Pd) termasuk anggota dan pengurus dari organisasi Persatuan Tunanetra Indonesia (skala nasional) sebagai seksi pendidikan keagamaan dan pendidikan teknologi sejak tahun 2007-sekarang (disarankan jadi ketua), selain itu organisasi lain dalam wilayah Kalimantan Timur aktif sebagai ketua pada organisasi ITMI (Ikatan Tunanetra Muslim Indonesia).

\section{Keadaan Siswa SMPLB Negeri Balikpapan}

Keadaan siswa SMP LBN Balikpapan untuk tahun ajaran 2012-1013 terdapat penyandang tunarungu, tuna grahita, tunadaksa dan autis. Peserta didik yang akan mendaftar pada SLB Negeri Balikpapan memiliki peraturan yang sudah menjadi ketentuan dan persyaratan sekolah. Menurut R. Trionggo (Wakil Kepsek SLBN), siswa yang akan mendaftar dikenakan persyaratan melalui serangkaian tes, melengkapi surat keterangan dari dokter, surat keterangan orang tua, akta lahir, kartu keluarga, dan foto. Jumlah siswa SMPLB Negeri Balikpapan untuk tahun ajaran 2012-2013 dominan adalah tuna grahita baik sedang (C) maupun berat (C1), kemudian tunarungu, tunadaksa, dan autis. Anak yang memiliki disabilitas tunanetra tidak terdapat di SMPLB Negeri. Keberadaan siswa tunanetra yang merupakan alumni dari SDLB Negeri Balikpapan dominan melanjutkan pendidikannya ke SMP inklusif. Untuk lebih jelasnya data siswa SMPLB Negeri Balikpapan lihat tabel 1.

Tabel 1. Jumlah Siswa SMPLB Negeri Balikpapan

\begin{tabular}{|c|c|c|c|c|c|c|c|c|c|c|c|c|}
\hline \multirow{3}{*}{$\begin{array}{l}\frac{y}{n} \\
\frac{y}{\widetilde{z}} \\
\stackrel{Z}{4}\end{array}$} & \multicolumn{3}{|c|}{ Tingkat } & \multicolumn{3}{|c|}{ Tingkat } & \multicolumn{3}{|c|}{ Tingkat } & \multicolumn{3}{|c|}{ Jumlah } \\
\hline & \multirow{2}{*}{ 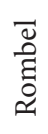 } & \multicolumn{2}{|c|}{ Siswa } & \multirow{2}{*}{$\begin{array}{l}\widetilde{\Xi} \\
\text { है } \\
\text { م્ય }\end{array}$} & \multicolumn{2}{|c|}{ Siswa } & \multirow{2}{*}{$\begin{array}{l}\vec{\Xi} \\
\text { हี } \\
\text { ટิ }\end{array}$} & \multicolumn{2}{|c|}{ Siswa } & \multirow{2}{*}{$\begin{array}{l}\vec{\varpi} \\
\text { है } \\
\text { ڤ્ }\end{array}$} & \multicolumn{2}{|c|}{ Siswa } \\
\hline & & $\mathrm{L}$ & $P$ & & $\mathrm{~L}$ & $P$ & & $\mathrm{~L}$ & $\mathrm{P}$ & & $\mathrm{L}$ & $\mathrm{P}$ \\
\hline A & - & - & & - & - & & - & - & - & - & - & - \\
\hline B & 1 & 4 & 3 & 1 & 2 & 2 & 1 & 3 & 2 & 1 & 9 & 7 \\
\hline$C \& C 1$ & 1 & 7 & 8 & 1 & 7 & 2 & 1 & 8 & 3 & 1 & 22 & 13 \\
\hline $\mathrm{D}$ & - & 1 & 1 & 1 & 2 & - & 1 & 2 & 2 & 1 & 5 & 3 \\
\hline M & - & - & - & 1 & 1 & - & - & 4 & - & - & 5 & - \\
\hline
\end{tabular}

\section{Kurikulum}

SMPLB Negeri Balikpapan dalam proses pembelajarannya menggunakan kurikulum KTSP (wawancara St. Rohaeni, 12/4/2013), pada implementasinya lebih mengembangkan kurikulum yang menekankan penanaman karakter dalam rangka pembentukan pengetahuan dan pengalaman peserta didik agar kelak senantiasa menjadi pribadi yang berakhlak mulia sesuai dengan harapan dan tujuan pendidikan. Di samping itu, berdasarkan keberadaan SLB Negeri Balikpapan merupakan sub center dan piloting project pada 
standar sekolah berbudaya dan berkarakter 2010 . Dan juga sebagai sekolah piloting pendidikan anti korupsi tahun 2012. Berdasarkan Profil SLBNegeri Balikpapan kurikulum SMPLB Negeri Balikpapan meliputi: $48 \%$ program umum, program khusus, program muatan lokal, dan program pengembangan diri. $52 \%$ program pilihan, a) isi program umum kurikulum SMPLB disesuaikan dengan kurikulum sekolah lanjutan tingkat pertama dengan memperhatikan keterbatasan dan kemampuan belajar para siswa yang bersangkutan, b) isi program pilihan kurikulum SMPLB berupa paket-paket keterampilan yang dapat dipilih siswa dan diarahkan pada penguasaan satu jenis keterampilan atau lebih yang dapat menjadi bekal di masyarakat.

Tujuan Pendidikan Agama Islam di SMP/ MTs/SMPLB bertujuan untuk: a) Menumbuhkembangkan akidah melalui pemberian, pemupukan, dan pengembangan pengetahuan, penghayatan, pengamalan, pembiasaan, serta pengalaman peserta didik tentang agama Islam sehingga menjadi manusia muslim yang terus berkembang keimanan dan ketakwaannya kepada Allah swt; b) Mewujudkan manusia Indonesia yang taat beragama dan berakhlak mulia yaitu manusia yang berpengetahuan, rajin beribadah, cerdas, produktif, jujur, adil, etis, berdisiplin, bertoleransi, menjaga harmoni secara personal dan sosial serta mengembangkan budaya agama dalam komunitas sekolah.

Ruang lingkup Pendidikan Agama Islam meliputi aspek-aspek $\mathrm{Al}$ quran dan hadits, aqidah, akhlak, fiqih, dan tarikh dan hadharah. Di samping itu, materi tambahan lain yang menjadi titipan dari KPK yakni pendidikan Anti Korupsi. (wawancara Mulyono, 11/4/2013). Pendidikan anti korupsi ini terintegrasi semua mata pelajaran di masing-masing $\mathrm{RPP} /$ silabus. Peran guru dalam menanamkan nilainilai anti korupsi baik pada proses pembelajaran, dilingkungan sekolah, mau-pun lingkungan masyarakat sangat penting artinya sebagai upaya dini dalam mencegah korupsi sejak dini (Panduan Penyelenggaraan pendidikan Anti Korupsi Di Satuan Pendidikan, 2012: 24-25).

Enam diantara sembilan nilai anti korupsi beririsan langsung dengan 18 pendidikan karakter, yaitu: jujur, disiplin, tanggung jawab, kerja keras, mandiri, dan peduli. Sedangkan tiga nilai yaitu: adil, berani, dan sederhana secara implisit menjadi indikator dari nilai-nilai religius, toleransi, demokratis, dan peduli. Hal ini menguatkan bahwa Pendidikan Anti Korupsi menjadi bagian yang tidak terpisahkan dari pendidikan karakter.

\section{Metode Pembelajaran PAI}

Metode pembelajaran bagi anak berkebutuhan khusus hendaknya mempertimbangkan beberapa prinsip-prinsip metode, di antaranya: mempertimbangkan tujuan yang akan dicapai; mempertimbangkan kemampuan, kondisi dan karakteristik siswa; mempertimbangkan materi yang akan disampaikan; mempertimbangkan situasi kelas dan kesiapan siswa; memper-timbangkan fasilitas yang tersedia; mem-pertimbangkan keahlian guru sendiri dalam memakai metode yang tepat, apakah metode yang akan digunakan sesuai dengan kepribadian dirinya atau tidak; serta memperhatikan kekuatan dan kelemahan yang terdapat pada suatu metode, sebab tidak dapat dipastikan bahwa suatu metode baik dan cocok untuk semua materi pelajaran. Beberapa: yang biasa digunakan oleh guru PAI dalam proses pembelajaran:

Pembiasaan, metode ini digunakan bagi siswa berkebutuhan khusus yang tidak mampu untuk mengikuti proses pembelajaran. metode ini diberikan bagi siswa yang memiliki tingkat kecacatan berat seperti siswa tuna grahita berat atau autis. Ketidakmampuan siswa berkebutuhan khusus ini mengikuti pelajaran, metode pembiasaan diberikan sebagai upaya untuk mengembangkan pengetahuan agama siswa. Pembiasaan yang diberikan yakni pembiasaan mengucapkan salam kepada guru atau teman, jabat tangan kepada guru, dan lain-lain.

Ceramah, metode ceramah merupakan metode yang paling dominan digunakan di SLB Negeri Balikpapan, ceramah merupakan cara penyampaian materi pelajaran dengan memberi penjelasan atau deskripsi secara sepihak oleh guru yang bertujuan agar peserta didik memahami kesatuan bahan materi pelajaran tersebut.

Demonstrasi, metode demonstrasi merupakan metode yang menekankan pada aktivitas/praktek siswa secara langsung. Dengan metode ini siswa langsung mencontoh atau meniru atau mengerjakan sesuatu gerakan. Melalui : ini merupakan: yang sangat penting terutama pada anak yang berkebutuhan khusus yang pada gilirannya 
peserta didik diharapkan dapat meniru dan melakukan apa yang didemonstrasikan. Misalnya pada pembelajaran PAI yakni melakukan gerakan shalat, tata cara berwudhu atau dalam bentuk yang memerlukan gerakan-gerakan tertentu. Kegiatan ini pada bertujuan untuk menanamkan nilai-nilai sosial, nilai-nilai moral dan nilai-nilai keagamaan. Penerapan Metode demonstrasi ini, dilakukan dengan menetapkan kegiatan demonstrasi yang akan dilakukan, dengan mempertimbangkan alat dan bahan sebagai tambahan dalam melakukan demonstrasi terutama pada anak yang berkebutuhan khusus seperti tuna rungu, tuna grahita, tuna daksa, dan autis.

Tanya jawab, metode tanya jawab juga merupakan salah satu metode yang digunakan oleh guru PAI dalam proses pembelajaran. metode tanya jawab adalah metode interaksi antara siswa dan guru PAI dalam bentuk sebuah pertanyaan diajukan oleh guru dan oleh siswa menanggapi pertanyaan tersebut. metode ini oleh guru PAI diharapkan dapat memancing olah vokal siswa tuna rungu dalam persepsi bunyi/vokal.

Pemberian tugas, metode pemberian tugas merupakan metode dengan menugaskan siswa untuk melakukan serangkaian kegiatan di dalam kelas atau di luar jam pembelajaran PAI. Metode pemberian tugas dilakukan oleh siswa dengan tujuan tertentu. Khusus anak berkebutuhan khusus pemberian tugas dilakukan di dalam kelas dan luar jam pembelajaran atau menjadi pekerjaan rumah (PR). Pemberian tugas bagi siswa akan tumbuh kreativitas dan kebiasaan untuk melakukan serangkaian latihan dan kegiatan belajar di luar pembelajaran di samping memperoleh serangkaian pengetahuan atau ketrampilan.

Karya wisata, metode karya wisata merupakan metode dengan cara membawa siswa langsung ke lokasi/objek sasaran di luar kelas dengan cara membawa siswa langsung atau di lingkungan tertentu. Meskipun metode karya wisata merupakan program sekolah, metode karya wisata ini bertujuan menambah wawasan dan pengalaman siswa terhadap dunia luar terutama bagi anak berkebutuhan khusus. Lokasi yang pernah dikunjungi oleh siswa SLB Negeri Balikpapan diantaranya pabrik pembuatan tahu, kantor koran Balikpapan Pos, karnaval-karnaval budaya, dan lain-lain. Dalam karya wisata menjadi media yang sangat efektif dalam mengembangkan wawasan anak berkebutuhan khusus.
Ketersediaan media pembelajaran dan peralatan khusus bagi peserta didik disesuaikan dengan kebutuhan peserta didik. Menurut Suyitno, S.Pd.I (guru PAI) dalam pembelajaran Pendidikan Agama Islam media pembelajaran yang digunakan dalam proses pembelajaran di antaranya: tape recorder, hp (mendengarkan suara azan dan asmaul husnah), e-pen, komputer (CD/DVD) yang gunakan untuk memutar film yang berkaitan dengan pelajaran agama. Menurut Lismiati, S.Pd.I untuk media pembelajaran yang digunakan dalam pembelajaran PAI seperti alat peraga berkaitan materi, dan gambar-gambar. Penggunaan sumber belajar pada siswa berkebutuhan khusus oleh guru agama adalah di samping menggunakan buku-buku pegangan dari Diknas, juga menggunakan sumber yang berasal dari internet, perpustakaan sekolah, dan lain-lain.

\section{Pelaksanaan Pembelajaran Agama Islam SMPLB Negeri Balikpapan \\ Materi Pembelajaran PAI}

SMPLB Negeri Balikpapan memiliki struktur kurikulum yang menjadi ketentuan sekolah terdiri mata pelajaran umum (termasuk PAI), muatan lokal (Pendidikan Lingkungan Hidup), Program khusus (disesuaikan dengan kelainan dan kebutuhan siswa), dan pengembangan diri. Secara keseluruhan alokasi waktu 36 jam dengan ekuivalen 2 jam pelajaran masing-masing mata pelajaran. Berdasarkan struktur kurikulum SMPLB Negeri Balikpapan tersebut terimplementasi melalui pendekatan tematik. Pembelajaran tematik merupakan pembelajaran terpadu yang menggunakan tema untuk mengaitkan beberapa mata pelajaran sehingga dapat memberikan pengalaman belajar yang bermakna kepada siswa berkebutuhan khusus.

Pembelajaran agama Islam yang diterapkan pada peserta didik SMPLBN khususnya pada anak berkebutuhan khusus tuna rungu (B), dan tuna grhahita (C dan $\mathrm{C} 1$ ), tuna grhahita dan autis) merupakan materi pelajaran berdasarkan SK dan KD yang sudah di tetapkan yakni kurikulum KTSP berdasarkan BNSP. Lebih lanjut implementasi pembelajaran meski pada kenyataannya disesuaikan dengan standar dan kemampuan peserta didik. Menurut Lismiati, S.Pd (guru PAI), pembelajaran agama pada kenyataannya diajarkan berdasarkan standar yang sudah direncanakan namun pada implementasinya terkadang tidak terimplementasi sesuai dengan harapan.Menghadapi anak yang 
memiliki ke-butuhan khusus jauh berbeda dengan peserta didik normal pada umumnya. Pembelajaran yang diberikan terkadang lambat dipahami oleh siswa terutama peserta didik tuna grahita berat dan autis.

\section{Perencanaan Pembelajaran PAI}

Kegiatan pembelajaran merupakan tahapan setelah seperangkat persiapan telah dilakukan dan direncanakan. Dalam pelaksanaan ini guru dituntut untuk menyesuaikan pembelajaran yang akan dilakukan. Hal ini yang menjadi pertimbangan karena anak yang dihadapi adalah anak yang berbeda yakni anak yang berkebutuhan khusus. Keragaman kebutuhan khusus siswa yang dimiliki, baik pada siswa tuna grahita, tuna rungu, tuna daksa, dan autis sangat bervariasi, diantaranya:

Tuna grahita ( $\mathrm{C}$ dan $\mathrm{C} 1)$, siswa tuna grahita SMPLB Negeri Balikpapan merupakan siswa paling dominan, sangat bervariasi di antaranya tuna grahita ringan, sedang, dan berat. Kemampuan dan kompetensi guru dituntut memiliki keahlian dalam menghadapi anak tuna grahita dengan berbagai tingkatan. Tingkatan tuna grahita ini, dalam proses pembelajaran tetap berdasarkan dengan rencana yang telah disusun, meskipun implementasi pembelajaran disesuaikan dengan kemampuan yang dimiliki siswa tuna grahita. Pembelajaran PAI diberikan kepada siswa tuna grahita SMPLB dengan memperhatikan: materi PAI yang dianggap sulit disederhanakan, materi PAI menghindari materi yang bersifat abstrak, pemberian materi bertahap dan berulang (sering lupa), serta materi PAI disesuaikan dengan kemampuan siswa.

Tunarungu, pembelajaran PAI bagi siswa tunarungu sangat perlu memperhatikan pendekatan yang digunakan mengingat siswa tunarungu memiliki gangguan pendengaran. Penggunaan pola total komunikasi (bahasa isyarat, bahasa jari, menggali kemampuan berbicara, dan tatap muka langsung) dalam pembelajaran digunakan oleh guru PAI. Pada pembelajaran PAI di kelas siswa tunarungu menggunakan pendekatan individual, kelompok, dan pembiasaan. Pada aspek alat bantu bagi siswa tunarungu juga sangat diperlukan sebagai upaya dalam memberi peluang lebih besar bagi siswa tunarungu agar lebih cepat menangkap materi pembelajaran PAI.

Tuna daksa dan autis merupakan siswa yang mengalami hambatan pada fungsi gerak/fisiknya sehingga untuk mengembangkan potensi yang dimilikinya diperlukan pelayanan khusus. Dalam pembelajaran PAI, guru berusaha membimbing mereka sesuai dengan kemampuan yang mereka miliki agar mereka dapat mengembangkan potensinya secara maksimal. Dan bagi siswa berkebutuhan khusus seperti autis yang memiliki kelainan yang sulit, diperlukan strategi khusus dalam pembelajaran PAI, dengan ciri yang melekat pada siswa autis misalnya menghindari kontak mata, sulit berkata kata, asyik bermain sendiri, aktif bergerak, emosi tidak stabil, dan lain-lain. Kondisi ini menyulitkan siswa untuk melakukan pembelajaran. Dengan kondisi demikian pembelajaran yang diberikan dominan hanya melalui pembiasaan.

\section{Pengelolaan Kelas}

Untuk pembelajaran pendidikan pengelolaan kelas dilakukan sebagaimana pengelolaan kelas pada sekolah umum, untuk pembelajaran dilakukan antara guru dan murid diatur secara tatap muka dengan menggunakan jadwal pertemuan dan alokasi waktu sesuai dengan jam pelajaran. Pengelolaan kelas pada masing-masing kelas berisi antara lima sampai sepuluh siswa atau tergolong kelas kecil dan kegiatan pembelajaran dilaksanakan pada pagi hari jam 08.00 sampai 12.00. jumlah jam pelajaran pada satu kali tatap muka antara dua sampai tiga jam pelajaran. satu jam pelajaran untuk pembelajaran Pendidikan Agama Islam 40 menit. Kriteria Ketuntasan Minimal (KKM) mata pelajaran PAI pada SMPLB Negeri Balikpapan adalah $70 \%$. Untuk jumlah tatap muka bagi masing-masing guru di SLB Negeri Balikpapan untuk semua mata pelajaran antara 24 sampai 32 jam, khusus mata pelajaran Pendidikan Agama Islam (PAI) adalah 30 jam.

Pada proses pembelajaran PAI bagi siswa berkebutuhan khusus SMPLB Negeri Balikpapan dalam satu kelas dengan variasi kemampuan menerima pelajaran terkadang dilakukan dengan membagi papan tulis menjadi tiga bagian. Satu bagian untuk siswa yang sudah mampu, satu bagian bagi siswa yang mampu, dan satu bagian bagi siswa yang kurang mampu dalam menangkap materi yang sama. Misalnya dalam materi menyebutkan urutan dalam tatacara shalat. Terkadang pada pembelajaran yang dilakukan juga sering menggabungkan siswa tuna rungu, tuna grahita, tuna daksa, dan autis (berdasarkan disabilitas siswa yang ada). 


\section{Model Interaksi Pembelajaran PAI}

Model interaksi dalam pembelajaran PAI yang dominan dilakukan oleh guru di kelas SMPLB Negeri Balikpapan adalah model yang berusaha memberikan kemudahan bagi siswa yang berkebutuhan khusus (tuna rungu, tuna grahita, dan tuna daksa) dalam menerima pelajaran yang diberikan. Adapun pola yang digunakan dalam interaksi belajar mengajar PAI pada SMPLB Negeri Balikpapan pada sebagai berikut:

Model interaksi satu arah. Model ini digunakan oleh guru-guru Pendidikan Agama Islam pada SMPLBN. Model ini memberikan ruang kepada guru untuk lebih aktif di depan siswa terutama dalam menyampaikan materi sampai selesai dibahas. Pada model ini siswa hanya mendengarkan materi dibahas dan dijelaskan oleh guru PAI bersangkutan.

Model interaksi dua arah. Model komunikasi dua arah oleh guru Pendidikan Agama Islam, yakni model komunikasi yang lebih fleksibel karena ada keterlibatan antara guru dan siswa.Model ini bertujuan melibatkan siswa dalam proses kegiatan belajar mengajar. Dalam model komunikasi dua arah ini guru sering kali mencoba agar anak berkebutuhan khusus baik tunarungu, tuna grahita, dan tunadaksa, memberikan umpan balik terhadap materi yang disajikan oleh guru PAI. Meski pada kenyataannya apa yang dikomunikasikan (materi) belum semuanya dipahami oleh siswa (tergantung tingkat dan kemampuan siswa berkebutuhan khusus memahami materi yang dipelajari).

Model interaksi melingkar. Model ini biasanya diberikan kepada siswa berkebutuhan khusus pada saat setelah penyajian materi. Model ini cukup efektif dengan melibatkan siswa dengan cara memberikan kesempatan siswa secara bergiliran satu persatu baik yang bersifat menjawab pertanyaan guru, maupun yang bersifat praktik (baik membaca atau naik kedepan kelas untuk menghafal secara bergilir atau dibangku masing-masing). Model ini cukup menarik dengan melibatkan siswa berkebutuhan khusus yang secara tidak langsung memberikan peluang kepada guru untuk memberikan bimbingan langsung kepada siswa jika dalam memberi jawaban atau bacaan serta praktik yang diberikan terdapat kesalahan dan siswa dapat langsung memperbaiki kesalahan yang dilakukan.

Untuk mencapai suatu kompetensi dasar dalam kegiatan pembelajaran PAI tercantum langkah-langkah kegiatan dalam setiap pertemuan. Menurut Lismiati, Suyitno, dan Norberta Nuar, (wawancara, 18/4/2013) langkah-langkah kegiatan pembelajaran PAI memuat unsur kegiatan pendahuluan, kegiatan inti, dan kegiatan penutup. Pada proses pembelajaran yang dilakukan oleh guru PAI di kelas dari observasi yang dilakukan pada kelas tuna grahita SMPLB kelas VIII dengan materi standar kompetensi: mengartikan surah al Maun, kompetensi dasar: mengartikan surah Al Ma'un. Materi ini merupakan materi pembelajaran SD kelas V semester II.

Pendahuluan, merupakan kegiatan awal dalam pertemuan pembelajaran yang ditujukan untuk membangkitkan motivasi dan memfokuskan perhatian peserta didik untuk berpartisipasi aktif dalam proses pembelajaran. Pada kegiatan pendahuluan interaksi yang dilakukan oleh guru beserta siswa. Mengawali pembelajaran PAI seluruh siswa melakukan doa bersama. Isi doa pembuka adalah "Ya Allah, Ya Tuhan ku terima kasih atas karunia-Mu yang telah Kau berikan kepadaku, dan berilah kami kemudahan dalam menuntut ilmu, Amin. Kemudian dilanjutkan dengan mengucapkan salam dan membaca surah-surah pendek seperti: surah al-Fatihah, al Ikhlas, dan al Kautsar (tergantung surah-surah yang pernah dipelajari pada kelas bersangkutan); guru mengecek keadaan siswa (kehadiran); guru memberi tahu materi (kompetensi dasar dan standar kompetensi); guru memancing siswa dengan bertanya siapa yang sudah hafal surah Al Maun?, dan mengajak siswa tadarus bersama; guru menempelkan alat peraga berupa tulisan surah Al Maun (huruf Arab dan tulisan bahasa Indonesia) di papan tulis. (masih ada siswa yang sulit membaca huruf hijaiyah).

Kegiatan inti, merupakan proses pembelajaran untuk mencapai KD. Kegiatan pembelajaran dilakukan secara interaktif, inspiratif, menyenangkan, menantang, memotivasi peserta didik untuk berpartisipasi aktif, serta memberikan ruang yang cukup bagi prakarsa, kreativitas, dan kemandirian sesuai dengan bakat, minat, dan perkembangan fisik serta psikologis peserta didik. Kegiatan ini dilakukan secara sistematis dan sistemik melalui proses eksplorasi, elaborasi, dan konfirmasi, di antaranya: guru menjelaskan materi; guru menyampaikan materi dengan bahasa yang digunakan adalah nasional (Indonesia); selanjutnya guru melibatkan partisipasi siswa yaitu dengan cara melibatkan siswa untuk membaca bersama dan kemudian membaca secara berkelompok (siswa mengulang-ulang bacaan surah Al Maun); langkah 
selanjutnya guru melakukan tahap individual, yaitu murid satu persatu siswa membaca didepan kelas, dengan menunjuk nama siswa dengan suasana keakraban. Ada siswa yang membaca dengan lancar, ada siswa yang merespon dengan naik kedepan kelas sambil mengikuti tuntunan guru mengenai bacaan, ada yang hanya membaca dengan komat kamit, akan tetapi ada juga yang duduk dan sembunyi di bawah meja ketika tiba gilirannya. Guru juga menuntun siswa dalam melafazkan surah Al Mảun dengan benar. Materi bacaan surah-surah pendek juga diberikan pada kegiatan pesantren ramadhan.

Kegiatan Penutup, merupakan kegiatan yang dilakukan untuk mengakhiri aktivitas pembelajaran yang dapat dilakukan dalam bentuk rangkuman atau kesimpulan, penilaian dan refleksi, umpan balik, dan tindak lanjut, di antaranya tahap ini merupakan langkah setelah kegiatan pembelajaran selesai, yaitu guru menyimpulkan materi dan bersama sama siswa untuk melafalkan kembali materi yang telah dipelajari. Guru motivasi siswa untuk selalu membaca surah Al Maun ketika shalat. Menutup kegiatan yakni guru memberi motivasi agar tetap rajin belajar serta membaca doa bersama. Doa penutup adalah: Ya Allah Ya Tuhan ku terima kasih atas karunia yang telah Kau berikan kepada $k u$, dan berilah kami keselamatan sampai di rumah. Amin. Kemudian dilanjutkan dengan salam.

\section{Evaluasi Pembelajaran PAI Sistem Evaluasi}

Evaluasi digunakan mengukur pengetahuan dan pemahaman siswa setelah kegiatan interaksi belajar mengajar PAI, evaluasi yang dilakukan yakni pada tiga aspek, afektif, psikomotor, dan kognitif. pelaksanaan evaluasi pada anak berkebutuhan khusus siswa SMPLB pada siswa tuna rungu, tuna grahita, dan tuna daksa menggunakan sistem (disesuaikan dengan kebutuhan siswa), yakni: evaluasi berbasis kelas (seperti pertanyaan lisan, ulangan harian, tugas individu, dan semester) dan evaluasi berbasis sekolah.

\section{Pendukung dan Penghambat Pembelajaran Agama di SMPLB Negeri Balikpapan}

Proses pembelajaran PAI pada SMPLB Negeri

Balikpapan selama ini berjalan berkat dukungan dan kinerja berbagai pihak di antaranya: kepemimpinan kepala sekolah yang mempunyai peranan penting dalam mengembangkan budata sekolah, terutama budaya organisasi SLB, mendorong kinerja dan motivasi guru, melakukan kerjasama dengan berbagai pihak dalam upaya mengembangkan sekolah.

Keberadaan guru PAI bagi siswa berkebutuhan khusus di samping profesional yang dimiliki guru, ketika dalam pembelajaran mencerminkan guru yang demokratis (memberi kebebasan kepada siswa dengan batasan-batasan tertentu), sabar dalam menghadapi siswa berkebutuhan khusus dengan berbagai karakter, adil dengan tidak membedabedakan siswa, suka humour terhadap siswa, menguasai bahan pelajaran, dan menaruh perhatian lebih kepada minat siswa berkebutuhan khusus.

Jumlah siswa yang banyak, merupakan faktor pendukung dalam proses pembelajaran. Dalam beberapa tahun terakhir SMPLB Negeri Balikpapan khususnya sangat kewalahan dalam menghadapi jumlah siswa yang berminat untuk belajar di SMPLB.

Orang tua siswa, perhatian orang tua siswa sangat mendukung terutama dalam kegiatan yang dilakukan sekolah, khusus pada kegiatan keagamaan yang sudah menjadi agenda sekolah. Perhatian dan minat siswa dalam pembelajaran PAI sangat tinggi, baik pembelajaran yang dilakukan di dalam kelas maupun dalam kegiatan keagamaan yang sudah diprogramkan.

Terdapat pula penghambat pembelajaran berupa kekurangan guru Pendidikan Agama Islam, siswa di SLB Negeri Balikpapan sudah melebihi kapasitas daya tampung, jika dibandingkan dengan tenaga pendidik tidak sebanding antara output dan input. Jika tidak dapat segera diatasi akan menghambat hak anak berkebutuhan khusus untuk memperoleh pendidikan.

Penggunaan media pembelajaran dan peralatan khusus bagi peserta didik yang memiliki gangguan, (tuna rungu/B) adalah alat hearing aids (alat bantu dengar), audiovisual, tape recorder, gambar-gambar, alat-alat bina komunikasi persepsi bunyi dan irama. Media pembelajaran dan peralatan khusus bagi peserta didik tuna grahita ( $\mathrm{C}$ dan $\mathrm{C} 1$ ) misalnya: peralatan konsep dan simbol-simbol huruf hijaiyah, peralatan pengajaran bahasa, dan lain-lain. Media pembelajaran dan peralatan peserta didik tuna daksa misalnya peralatan alat bantu belajar. metode dan pendekatan dalam pembelajaran PAI hendaknya disesuaikan dengan kebutuhan siswa berkebutuhan khusus, terutama siswa yang sulit dalam membaca materi PAI huruf hijaiyah.

Sarana dan prasarana yang mendukung pembelajaran agama misalnya media perangkat 
ibadah, tempat praktek ibadah (tempat wudhu dan masjid).Sumber buku-buku agama seperti buku hadis, cerita agama (kisah-kisah nabi sahabat, dan lain-lain) sebagai sumber referensi bagi guru dan siswa.

\section{PENUTUP}

Hasil penelitian yang telah dilakukan terhadap pelaksanaan Pendidikan Agama Islam pada SMPLB Negeri Balikpapan, disimpulkan bahwa SMPLB Negeri Balikpapan dalam pelaksanaan pembelajaran PAI menggunakan kurikulum KTSP. Pada implementasinya mengembangkan kurikulum yang menekankan penanaman karakter dengan pendekatan tematik. Serta melengkapi kurikulum yang ada dengan materi pendidikan anti korupsi. Meski pada kenyataannya pelaksanaan pembelajaran PAI disesuaikan dengan standar dan kemampuan anak berkebutuhan khusus.Langkah pembelajaran PAI yang diterapkan dengan model pembelajaran interaksi satu arah, interaksi dua arah, dan model interaksi melingkar.Ketersediaan media pembelajaran yang digunakan pada pembelajaran PAI merupakan media elektronik dan non elektronik.Pada tahap akhir pembelajaran evaluasi tidak di sarankan bagi semua siswa kecuali bagi siswa yang mampu mengikuti evaluasi tersebut dengan bentuk evaluasi PAI yakni evaluasi berbasis kelas dan berbasis sekolah.

Faktor pendukung pelaksanaan pembelajaran agama siswa SMPLB diantaranya kepemimpinan kepala sekolah, profesionalitas guru PAI, keberadaan siswa yang banyak, perhatian orang tua siswa, dan minat siswa dalam pembelajaran PAI sangat tinggi, baik pembelajaran yang dilakukan di kelas maupun dalam kegiatan keagamaan yang sudah diprogramkan. Faktor penghambat, diantaranya kurangnya guru PAI, penggunaan media pembelajaran dan peralatan khusus bagi peserta didik yang memiliki gangguan pendengaran misalnya siswa tuna rungu, tuna grahita, dan tuna daksa. Pendekatan dalam pembelajaran PAI hendaknya disesuaikan dengan kebutuhan siswa berkebutuhan khusus, terutama siswa yang sulit dalam membaca materi PAI huruf hijaiyah. Sarana dan prasarana yang mendukung pembelajaran agama misalnya media perangkat ibadah, tempat praktek ibadah (tempat wudhu dan masjid). Dan sumber buku-buku agama seperti buku hadits, cerita agama (kisah-kisah nabi sahabat, dan lainlain) sebagai sumber referensi bagi guru dan siswa.

\section{UCAPAN TERIMA KASIH}

Tulisan ini hadir tidak terlepas dari bantuan berbagai pihak, ucapan terima kasih penulishaturkan kepada Kepala Balai Penelitian dan Pengembangan Agama yang telah menempatkan peneliti di Kota Balikpapan, dan terkhusus Kepala SLB Negeri Balikpapan Bapak Mulyono yang telah memberi izin melakukan penelitian, Bapak dan ibu guru SLB diantaranya: Bapak R. Trionggo, Ibu St. Rohani, Ibu Lismiyati, Bapak Suyitno, Ibu Nur Berta, dan kepada bapak dan ibu guru SLB Negeri Balikpapan, pengawas SLB, dan pihak-pihak yang tidak dapat penulis sebutkan satu persatu, atas bantuannya dan partisipasinya kepada peneliti dalam pengumpulan data lapangan. Dan kepada rekan-rekan peneliti yang telah memberikan sumbang saran, kritik dan masukannya untuk melengkapi tulisan ini. Ucapan yang sama penulis haturkan kepada tim redaksi AlQalam yang telah menjadikan tulisan ini sebagai salah satu bagian tulisan dalam jurnal Al-Qalam pada edisi ini.

\section{DAFTAR PUSTAKA}

Abdurrahman, Mulyono. 2003. Pendidikan Bagi Anak Berkesulitan Belajar. Jakarta: Depdikbud Dirjen Pendidikan Tinggi Proyek Pendidikan Tenaga Akademik dan Rhineka Cipta.

Bogdan, Robert C. \& Sari Knopp Biklen. 1982. Qualitative research for education. Boston. Allyn and Bacon inc.

Gate, Arthur T Jersild, TR. Mc Connell, and Robert C. Challman. 1950. Education Psychology. New York: The Macmillan Company.

Mulyono. 1994. Pendidikan Luar Biasa Umum. Pendidikan Jakarta: Ditjen $\mathrm{p}$ Tinggi Depdiknas.

Nuraeni. 1997. Intervensi Dini Bagi Anak Bermasalah. Jakarta: Rineka Cipta.

Panduan Penyelenggaraan Pendidikan Anti Korupsi Di Satuan pendidikan, Kementerian Pendidikan Dan Kebudayaan didukung oleh Komisi Pemberantasan Korupsi 2012.

Profil SLB Negeri Balikpapan 2013.

Sagala, Syaiful. 2005. Konsep dan Makna Pembelajaran. Bandung: Alfa.

Sopandi, Evi. 2009. 'Jurnal Penelitian Pendidikan dan Keagamaan'. Edukasi Volume. VII Nomor. 4. Oktober-Desember. 
Strauss, Anselm dan Juliet Corbin. 2007.Basic of Qualitative Research Grounded Theory Procedures and Techniques), terj. Dasar-dasar Penelitian Kualitatif, terj. Muhammad Sodiq dan Imam Muttaqien. Yogyakarta: Pustaka Pelajar.

Sugiyono. 2005. Memahami Penelitian Kualitati. Bandung: Alfabeta.

Thoha, Chalib (eds). 1994.Metodologi Pengajaran
Agama.Yogyakarta: Pustaka Pelajar.

Yusuf, Munawir. 2005. Pendidikan Bagi Anak Problema Belajar. Jakarta: Depdiknas.

Peraturan Menteri Agama RI Nomor 16 Tahun 2010 Tentang Pengelolaan Pendidikan Pada Sekolah.

Undang-Undang No. 20 Tahun 2003 Tentang Sisdiknas

SK Kepala Dinas Pendidikan Provinsi Kalimantan timur Nomor 90/K.827/IV/2006. 